\title{
EPIDEMIOLOGY EVALUATION OF ATHLETIC INJURY IN UNIVERSITY CENTER
}

Pedro Rocha Tenorio', Jean Kleber Oliveira da Silva' ${ }^{1}$, Mariana Emanuele Higa de Melo', Me. Thaoan Bruno Mariano'.

${ }^{1}$ Faculdade de Fisioterapia, Universidade do Oeste Paulista.

\section{SUMMARY BOX}

- College athletics appears to have a high incidence of injury.

- There is an unusually high number of severe injuries in college athletic athletes participating in the study.

- Most college athletic sports injuries do not appear to be diagnosed or properly treated.

- Most injuries are concentrated in the lower body.

\section{ABSTRACT}

Introduction: Athletics is a sport with varied modalities, which are based on patterns and activities that are natural to human beings. As a sport, it has several benefits, such as improved physical condition and interpersonal interactions, but it is not free from risks, especially injuries related to competitions or training.

Objectives: Characterize injuries presented by the university athletics group of the medical course and identify possible risk factors.

Methods: Participants, enrolled in the athletics group of the medicine course, of both sexes, had anthropometric measurements evaluated and answered an injury screening questionnaire modified from the "Injury Surveillance System".

Results: 31 participants responded to the questionnaire where $65 \%$ of them had at least one injury. A total of 23 injuries were reported, 20 of which were severe,

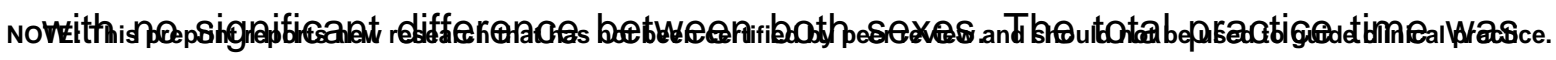


medRxiv preprint doi: https://doi.org/10.1101/2021.11.02.21265630; this version posted November 7, 2021. The copyright holder for this

almost 2 times longer in injured practitioners than in non-injured ones. Conclusion: The practice of university athletics is associated with a high occurrence of severe injuries.

Keywords: Athletics. Injury. Epidemiology, Sport, Health.

\section{INTRODUCTION}

The practice of physical activity has several recognized health benefits, such as increased physical capacity and disease prevention, as well as secondary benefits such as reduced drug use, psychosocial effects, and personal development ${ }^{1}$. However, there are also negative effects related to the practice of physical activity, such as eating disorders ${ }^{1}$ and in particular, especially in practitioners who aim to improve performance, particularly for competition, increasing the rate of injuries².

Although college sports in Brazil are not as expressive as in other places, such as the United States, where the practice is related to professional careers or scholarships $^{3}$, there are still several sporting events promoted by university athletes in the country, organized by the national governing body responsible, the CBDU (Brazilian Confederation of University Sports) ${ }^{2}$. Several modalities of athletics are included in these competitions and are practiced by university centers throughout Brazil. This competitions are based on the execution of natural human movements, and therefore, can be considered a basic activity for the acquisition of motor skills for various purposes ${ }^{3}$.

The risk of injuries in athletes is higher than in the general population, varying according to the modality practiced, training volume, specialization, among other factors $^{4-6}$. The time taken away from training and competitions due to the injury can vary greatly depending on the region and severity of the injury and the type 
of treatment applied, ranging from a few days ${ }^{7}$ to several months in surgical cases $^{3}$.

Among Brazilian research, scientific production focused on Athletics modalities is still scarce, mostly focused on speed events ${ }^{3}$ and from the few studies on injury in sport, only 1 was found where the injury in college athletes was discussed ${ }^{3}$. The University of Oeste Paulista (Unoeste) has an athletics group of students enrolled in the medical course, already with a history of competitions. However, there is no described characterization of these individuals, thus an epidemiological assessment of the lesions presented by the participants was carried out to identify injuries and possible risk correlations.

\section{METHODS}

\section{Ethical Considerations}

The study followed all ethical standards for experimentation and was approved by the CEP and registered with the CPDI-UNOESTE under number 6991.

\section{Recruiting Subjects}

Subjects enrolled during the period of January to October 2021 in the athletics group of the medical course of the Universidade do Oeste Paulista, of both sexes, were invited to participate in the study after signing the Informed Consent Form.

\section{Anthropometric Evaluation}

The height and weight of the participants were collected individually using a Mi

Body Composition Scale 2 (Xiaomi, Beijing, China) and a measuring tape.

\section{Injury Evaluation}

Subsequently, a modified retrospective version of the questionnaire "Injury Surveillance System" (ISS) ${ }^{8}$ was applied, which contained information on the 
modality practiced during the injury, injury site, date of injury, mechanism of injury, clinical and physical therapy diagnosis, and treatment adopted.

\section{Data Analysis}

The $X^{2}$ test was applied in order to compare the presence or absence of injury according to gender, age, height, weight, BMI, weekly training time, and total time of practice of the sport. To assess the difference between the sample characteristics of men and women, the unpaired t-student test was used. It was assumed a significance level of 5\%. The software used was SPSS Statiscs (V.20, IBM, Armonk, New York, USA).

\section{RESULTS}

A total of 31 subjects completed the questionnaire, a $96,875 \%$ answer rate.

\section{Subjects Characterization}

The sample characterization can be seen in Table 1 . The most practiced modality was the 100 meters dash (61.3\%). The distribution of the modalities practiced can be seen in Table 2 .

\begin{tabular}{|c|c|c|}
\hline \multicolumn{2}{|l|}{ Table 1. Sample Caracterization } & Female \\
\hline $\mathrm{N}$ & 12 & 19 \\
\hline Age (years) & $22,92 \pm 2,35$ & $22,74 \pm 3,28$ \\
\hline Hight $(\mathrm{m})$ & $1,79 \pm 0,06^{*}$ & $1,65 \pm 0,07^{*}$ \\
\hline Weight $(\mathrm{Kg})$ & $81,08 \pm 13,30^{*}$ & $62,3 \pm 11,1^{*}$ \\
\hline BMI $\left(\mathrm{Kg} / \mathrm{m}^{2}\right)$ & $25,37 \pm 4,53$ & $22,73 \pm 3,33$ \\
\hline $\mathrm{T}(\mathrm{h})$ & $7,83 \pm 3,3$ & $7,34 \pm 3,6$ \\
\hline
\end{tabular}

$\mathrm{N}=$ number of participants; $\mathrm{T}=$ Time of semanal training 
medRxiv preprint doi: https://doi.org/10.1101/2021.11.02.21265630; this version posted November 7, 2021. The copyright holder for this preprint (which was not certified by peer review) is the author/funder, who has granted medRxiv a license to display the preprint in It is made available under a CC-BY-NC-ND 4.0 International license .

\begin{tabular}{|c|c|}
\hline Table 2. Number of participants by modality \\
\hline Modality & Participants (n) \\
\hline $100 \mathrm{~m}$ & 19 \\
\hline $400 \mathrm{~m}$ & 9 \\
\hline $1500 \mathrm{~m}$ & 6 \\
\hline $5000 \mathrm{~m}$ & 2 \\
\hline $4 \times 100 \mathrm{~m}$ relay & 9 \\
\hline $4 \times 400 \mathrm{~m}$ relay & 4 \\
\hline Shot put & 7 \\
\hline Discus throw & 3 \\
\hline Javelin & 3 \\
\hline Long Jump & 3 \\
\hline High Jump & 3 \\
\hline Triple Jump & 2 \\
\hline
\end{tabular}

$\mathrm{n}=$ number of participants

\section{Injuries Characterization}

A total of 23 injuries were found. $52.6 \%$ of women and $83.3 \%$ of men had at least 1 injury, but there was no statistically significant difference between the incidence of injury between the two sexes. The anatomical location of injury incidence can be seen in Table 3. Of the 31 athletes, 20 had at least one and 3 had two injuries. All injuries recorded occurred during training, with 2 occurring during warm-up, 9 during the first half of training, 7 during the second half of training, and 5 during the cool-down period. Of the 23 injuries recorded, 20 were new injuries, 2 were recurrence of a previous injury occurring in the practice of the same modality and 1 was due to a complication of a previous injury resulting from another athletics modality. 2 of the injuries led to the participants' permanent removal from the sport, 3 injuries did not lead to any time off, and the meantime time off for the other injuries was 52.83 days, with a minimum of 7 days and a maximum of 6 months. The types of injuries can be seen in Table 4 .

Table 3. Incidence of injury by anatomical location

\begin{tabular}{|c|c|}
\hline Injury Site & Incidence $(\mathrm{n})$ \\
\hline Shin & $6(28,57 \%)$ \\
\hline Quadriceps & $5(23.81 \%)$ \\
\hline Hamstrings & $3(14,29 \%)$ \\
\hline
\end{tabular}


medRxiv preprint doi: https://doi.org/10.1101/2021.11.02.21265630; this version posted November 7, 2021. The copyright holder for this preprint (which was not certified by peer review) is the author/funder, who has granted medRxiv a license to display the preprint in It is made available under a CC-BY-NC-ND 4.0 International license .

\begin{tabular}{|c|c|}
\hline Knee & $3(14,29 \%)$ \\
\hline Patella & $2(9,52 \%)$ \\
\hline Ankle & $2(9,52 \%)$ \\
\hline
\end{tabular}

$\mathrm{n}=$ Number of injurys by region

$13(56.3 \%)$ lesions received clinical diagnosis and imaging exams were performed in 8 of them. 2 lesions were treated with non-steroidal antiinflammatory drugs for 5 and 7 days and another 2 were treated with prescribed dietary supplementation for 3 and 5 months. None of the lesions underwent surgical intervention. $11(47.8 \%)$ injuries were treated with physical therapy, 9 injuries had an average time of physical therapy treatment of $1.25 \pm 0.47$ months, the other 2 injuries had a discrepant treatment time of 6 and 16 months.

\begin{tabular}{|c|c|}
\hline Table 4. Incidence of type of injuries \\
\hline Type of Injuries & Incidence $(\mathrm{n})$ \\
\hline Incomplete Muscle Tear & $7(30,4 \%)$ \\
\hline Inflamation & $7(30,4 \%)$ \\
\hline Cartilage Damage & $3(13 \%)$ \\
\hline Incomplete Ligament Tear & $1(4,3 \%)$ \\
\hline Nerve Injury & $1(4,3 \%)$ \\
\hline Stress Fracture & $1(4,3 \%)$ \\
\hline Unknow & $3(13 \%)$ \\
\hline
\end{tabular}

$\mathrm{n}=$ Number of events

\section{Risk Factors}

The characteristics of injured and uninjured individuals can be seen in Table 5 . Statistical differences were observed between BMI $(p=0.037)$, where injured individuals presented a lower $\mathrm{BMI}$, and the length of total time in practice of the sport $(p=0.048)$, with a practice time almost twice as long in individuals who presented injuries.

\begin{tabular}{|c|c|c|}
\hline \multicolumn{3}{|c|}{ Table 5. Characterization of subjects with and without injuries } \\
\hline & With Injury (20) & Without Injury (11) \\
\hline Age (years) & $22,45 \pm 2,19$ & $23,45 \pm 3,3,96$ \\
\hline Hight $(\mathrm{m})$ & $1,72 \pm 0,1$ & $1,68 \pm 0,08$ \\
\hline Weight $(\mathrm{Kg})$ & $67,58 \pm 11,31$ & $73,18 \pm 20,27$ \\
\hline
\end{tabular}


medRxiv preprint doi: https://doi.org/10.1101/2021.11.02.21265630; this version posted November 7, 2021. The copyright holder for this preprint (which was not certified by peer review) is the author/funder, who has granted medRxiv a license to display the preprint in It is made available under a CC-BY-NC-ND 4.0 International license.

\begin{tabular}{|c|c|c|}
\hline BMI $\left(\mathrm{Kg} / \mathrm{m}^{2}\right)$ & $22,65 \pm 2,76^{*}$ & $25,74 \pm 5,15^{\star}$ \\
\hline Training $(\mathrm{h})$ & $7,32 \pm 3,34$ & $7,91 \pm 3,75$ \\
\hline Practice $($ months $)$ & $15,1 \pm 10,66^{\star}$ & $8 \pm 5,19^{\star}$ \\
\hline
\end{tabular}

${ }^{*}=\mathrm{p}<0,05$

\section{DISCUSSION}

\section{Injuries Incidence and Severity}

This study found a high incidence of injuries in a college athletic center, if significant levels of injuries classified as severe, defined as more than 10 days away ${ }^{8}$, with 20 of the 23 injuries reported reaching this criterion,

The total injury incidence is higher than the rate reported by Rosa et al. in a similar retrospective study with 585 participants, including athletics and other modalities, using a similar methodology $(74,19 \% \text { vs } 49,91 \%)^{9}$. Unfortunately, it was not possible to point out the data referring exclusively to athletics in Rosa et al. ${ }^{9}$ although using the avalable, although, using the available data, one possible reason for the greater total incidence of injury reported by us can be the data collection method and length of time analyzed. Rosa et al. ${ }^{9}$ collect data from participants of the last 20 years by e-mail, been the most part of them no longer active members of the college center. We collect data only from active members in presential form, this may confer a greater accuracy in the data report, reflecting more precise data.

Although was a higher incidence of injury than that found by Rosa et al. ${ }^{3}$, the incidence was similar to the injury rate in runners found in a recent systematic review conducted by Francis et al. with a total of 18,195 subjects $^{10}$. Since running was the main sport practiced by the analyzed group, this may explain the higher incidence of injury compared if other studies in athletics if greater variety in modalities. 
medRxiv preprint doi: https://doi.org/10.1101/2021.11.02.21265630; this version posted November 7, 2021. The copyright holder for this preprint (which was not certified by peer review) is the author/funder, who has granted medRxiv a license to display the preprint in It is made available under a CC-BY-NC-ND 4.0 International license .

The incidence of severe injuries was much higher in or findings than reported by Rose et al. We found almost $90 \%$ of severe injuries in injured athletes, where Rose et al. reported around $50 \%{ }^{9}$. This data may be a reflection of the type of injuries reported by the participants, such as ruptures, fractures, and cartilage damage. This length of time away can have a deleterious effect on the participants' lives as a whole, preventing the athletes to participate not just in sport, but in social and academic events too, compromising the physical and mental health. This findings demonstrate the strong need to implement injury prevention programs in college centers.

The recurrence of injuries was small, different from what was reported in a crosssection analysis of college-level athletes in 7 sports modality, conducted by Lemoyne et al. where 82 participants answered a surveyquestionnaire, in which he found an incidence of more than 2 injuries per athlete ${ }^{11}$. Probably the low recurrence of injuries was due to the long time off took by the athletes after an injury, which despite the negative effects that may have on the social e academic life of the athletes, may favor their complete recovery, preventing recurrence or complication of the injury. this shows the need for careful reasoning when deciding to reintegrate a participant in the sport after an injury, considering a proper balance between the negative effects of time off and possible reoccurrence and complication of injury.

\section{Injury Site}

The incidence of injury by anatomical location was similar to that found by Francis et al. ${ }^{10}$, indicating that the lower body of the participants was the region with greater effort demand and susceptibility to injuries, thus showing the critical area of concern in formulation of a injury prevention program. 
medRxiv preprint doi: https://doi.org/10.1101/2021.11.02.21265630; this version posted November 7, 2021. The copyright holder for this preprint (which was not certified by peer review) is the author/funder, who has granted medRxiv a license to display the preprint in It is made available under a CC-BY-NC-ND 4.0 International license .

\section{Risk Factors}

The lowest BMI presented by the participants who reported an injury contrasts with what is reported in the literature, which shows a greater risk of injury if greater $\mathrm{BMI}^{12}$. This finding may be explained by the greater amount of lean mass in participants without injuries, which would help to prevent them ${ }^{13}$. The practice time of the sport was also significantly longer in those who present some injury, as expected since longer practice time corresponds to a greater number of events for the occurrence of injuries ${ }^{14}$, and greater accumulated training volume, a risk factor for injuries ${ }^{2,8}$.

\section{Limitations}

The methodological limitations present in the study were its retrospective nature, which could lead to underreporting of minor injuries that were forgotten, or the accuracy of the reported data. Another present limitation due to the retrospective nature was the inaccuracy in the report of a second sports. Many individuals reported weight training for various intermittent periods but were not able to pinpoint the duration or lenght of the training periods, this may be a confounding factor in the risk of injury. The low number of participants can also be a limiting factor for identifying risk factors for injuries.

\section{CONCLUSION}

College athletics seems to be a practice with a high prevalence of injuries, especially severe injuries, and its main risk factor appears to be the total time spent in sports training. More studies are necessary, especially with a prospective character, in order to develop a better understanding of risk factors and allow a better formulation and implementation of preventive measures in university sports.

\section{REFERENCES}


1. Malm C, Jakobsson J, Isaksson A. Physical Activity and Sports-Real Health Benefits: A Review with Insight into the Public Health of Sweden. Sports. 2019;7(5):127.

2. Universitário CB do D. Institucional. 2021.

3. Frainer DE, Abad CCC, Pazin J. Análise da produção científica sobre atletismo no Brasil: uma revisão sistemática. Rev bras ciênc mov. 2017;25(1):199-211.

4. Wiersma AJ, Brou L, Fields SK, Comstock RD, Kerr ZY. Epidemiologic comparison of ankle injuries presenting to US emergency departments versus high school and collegiate athletic training settings. Inj Epidemiol. 2018;5(1).

5. Post EG, Bell DR, Trigsted SM, Pfaller AY, Hetzel SJ, Brooks MA, et al. Association of Competition Volume, Club Sports, and Sport Specialization With Sex and Lower Extremity Injury History in High School Athletes. Sports Health [Internet]. 2017 Nov 19;9(6):518-23. Available from: http://journals.sagepub.com/doi/10.1177/1941738117714160

6. Bell DR, Post EG, Biese K, Bay C, McLeod TV. Sport specialization and risk of overuse injuries: A systematic review with meta-Analysis. Pediatrics. 2018;142(3).

7. Camp CL, Dines JS, van der List JP, Conte S, Conway J, Altchek DW, et al. Summative Report on Time Out of Play for Major and Minor League Baseball: An Analysis of 49,955 Injuries From 2011 Through 2016. Am J Sports Med. 2018;46(7):1727-32. 
8. Dick R, Agel J, Marshall SW. National Collegiate Athletic Association Injury Surveillance System commentaries: introduction and methods. J Athl Train. 2009;44(2):173-82.

9. Rosa BB, Asperti AM, Helito CP, Demange MK, Fernandes TL, Hernandez AJ. Epidemiology of sports injuries on collegiate athletes at a single center. Acta Ortop Bras. 2014;22(6):321-4.

10. Francis $\mathrm{P}$, Whatman $\mathrm{C}$, Sheerin $\mathrm{K}$, Hume $\mathrm{P}$, Johnson MI. The proportion of lower limb running injuries by gender, anatomical location and specific pathology: A systematic review. J Sport Sci Med. 2019;18(1):21-31.

11. Lemoyne J, Poulin C, Richer N, Bussières A. Analyzing injuries among university-level athletes: Prevalence, patterns and risk factors. J Can Chiropr Assoc. 2017;61(2):83-7.

12. Chassé M, Fergusson DA, Chen $\mathrm{Y}$. Body mass index and the risk of injury in adults: A cross-sectional study. Int J Obes. 2014;38(11):1403-9.

13. Roelofs EJ, Smith-Ryan AE, Melvin MN, Wingfield HL, Trexler ET, Walker N. Muscle size, quality, and body composition: Characteristics of Division I cross-country runners. J Strength Cond Res. 2015;29(2):290-6.

14. Jones S, Almousa S, Gibb A, Allamby N, Mullen R, Andersen TE, et al. Injury Incidence, Prevalence and Severity in High-Level Male Youth Football: A Systematic Review. Vol. 49, Sports Medicine. 2019. p. 1879_ 99.

\section{DATA AVAILABILITY STATEMENT}


medRxiv preprint doi: https://doi.org/10.1101/2021.11.02.21265630; this version posted November 7, 2021. The copyright holder for this preprint (which was not certified by peer review) is the author/funder, who has granted medRxiv a license to display the preprint in It is made available under a CC-BY-NC-ND 4.0 International license .

Data are available upon reasonable request. Request to access the data will be considered by the authors, within the constraints of privacy and consente.

Data can be requested from Pedro Rocha Tenorio, https://orcid.org/0000-00031812-4792, rocha.pedro.t@gmail.com.

\section{PATIENT AND PUBLIC INVOLVEMENT}

Patients and/or the public were not involved in the design, or conduct, or reporting, or dissemination plans of this research.

\section{CONTRIBUTORS}

PRT contributed to the conception and design, analysis and interpretation of data, drafting of the manuscript, and final aprroval of the version to be publish. TBM contributed to the conception and design, revision, and final aprroval of the version to be publish. JKOS contributed to the aquisition of data, and revision. MEHM contributed to the aquisition of data, and revision. All gave final approval and agree to be accountable for all aspects of work ensuring integrity and accuracy. 